\title{
The Causes of Richie Tenenbaum's Suicide Attempt in The Royal Tenenbaums
}

\author{
Steffanie Preiffer \\ English Department, Faculty of Languages and Literature, Petra Christian University, Siwalankerto 121- \\ 131, Surabaya 60236, INDONESIA. \\ Email:m11415020@john.petra.ac.id
}

\begin{abstract}
This thesis discussed suicide action in a dramedy movie. In the movie, the decision of suicide begins with negative experiences in childhood which is experienced by Richie, one of the male characters in The Royal Tenenbaums. The purpose of this thesis is to show Richie's negative self-schema which exists during his childhood, influences how he sees himself and his surroundings. In addition, this thesis exists to reveal the reasons why Richie decides to attempt suicide in his adult life. The theory of negative selfschema shows that Richie's negative self-schema exists during his childhood is because of divorced parents and criticism. The interpersonal theory of suicide reveals that Richie's situation matches the criteria of someone who is able to kill himself. First, Richie sees himself as burden to others because he falls into self-hatred perspective and liability. Second, he has faced loneliness, the feeling of lack of reciprocal relationship, and the feeling of social disconnectedness which makes him has a low belongingness. Lastly, these situations make have the ability to do self-harm and strong desire to die. Those steps lead Richie to attempt suicide. Through this analysis, I found that self-esteem and social support give a strong impact for someone's suicide decision.
\end{abstract}

Keywords: Suicide attempt, negative self-schema, perceived burdensomeness, low belongingness, selfharm

\section{INTRODUCTION}

Dramedy or drama-comedy is a mixed genre between drama and comedy. Dramedy is a combination of the semi-narrative film (drama) with humor or jokes inside the movie. Usually, this genre has a slow plot and less action scene (Wheel, 2015). The term “dramedy" was popular since the 1980s (Mittell, 2004, p. 155). Since then, this mixed-genre spread in TV series in America and several countries. One of Dramedy movies' directors is Wes Anderson. He is wellknown for creating drama and comedy movies. Up until now, he created and directed The Grand Budapest Hotel (2014), Moonrise Kingdom (2012), Rushmore (1998), The Royal Tenenbaums (2001), Come Together: A Fashion Picture in Motion (2016), The Squid and the Whale (2005), Hotel Chevalier (2007), The Life Aquatic with Steve Zissou (2004), and Isle of Dogs (2018). From all of Anderson's movies, I choose to analyze The Royal Tenenbaums. The Royal Tenenbaums sets in New York. sets in New York. This movie tells about a bittersweet relationship in Tenenbaums family. The Tenenbaums consists of Royal as the father, Etheline as the mother, Chas as the first son, Richie as the second son and Margot as the adopted daughter. These children are successful in their fields, including Richie. He is a talented and successful tennis player since he is in third grade. Later, young Richie has to face the divorce of his parents. Afterward, he and his siblings live with their mom and move out when they become adults. Ironically, the children of Tenenbaums are not successful in their adult lives. Chas's business is not developing well and becomes a paranoid person after the death of his wife. Margot becomes jobless after she marries a doctor. Then, Richie retires from tennis at the age of 26, which makes him seclude himself in loneliness and depression. Then, he goes through more conflicts in his family and finds a bitter truth from his loved ones. One day, he decides to end 
his life but he could be saved. Because of this incident, Richie and the family begin to accept each other and reunite.

Richie's change -from a happy child to a suicidal adult- intrigues me. Richie undergoes many negative experiences since his childhood until in his adult life. Some difficult moments like losing a job, disappointment, and betrayal also played significant roles in causing him to become suicidal.

I would like to find out why Richie attempts suicide in The Royal Tenenbaums. Therefore, I want to show that Richie's decision to attempt suicide begins with his negative self-schema within him from the conflicts in his family and criticism during his childhood. Also, Richie's perceived burdensomeness, low belongingness, and ability to self-harm have led him to attempt suicide.

Dramedy like, The Royal Tenenbaums, can tackle a serious issue like suicide and make the audience aware of the reason behind the action of suicide. The comedy itself can be a tool for people to reflect their life instead of just a form of entertainment (Thorpe, 2019, para 9). Adding some issues like mental health issues in the dramedy movie can make people aware that mental health issues can happen to anyone. It is also good for people to freely discussed and to help people who have a mental illness to seek help (Thorpe, 2019, para 11).

I use the theory of negative self-schema and Interpersonal Theory of Suicide in finding why Richie decides to attempt suicide in The Royal Tenenbaums. Negative self-schema is people's view about themselves which begins from early life until adulthood. Negative Self-Schema exists during childhood life and occurs because of rejection, criticism, overprotective parents, bullying, death of family members, etc. The conflict like divorce can affect children's cognition and behavior that drive them into a negative concept. (Grych \& Fincham, 1990, p. 277). Negative self-schema can also bring low self-esteem to people (Kestinga \& Lincoln, 2013). Later, negative experiences remain in people's cognition. In the future, they will recall those unpleasant memories when they face another unpleasant situation. Thus, I use Negative SelfSchema in analyzing Richie's unpleasant childhood experience. The Interpersonal Theory of Suicide explains three important aspects that cause someone decide to end his or her life. The first aspect is Perceived Burdensomeness. This is the view when people tend to think that their existences are just a burden to their family, friends, and society. In addition, low self-esteem is a significant factor that creates perception of burdensomeness (Joiner T. E., Van Orden, Cukrowicz, \& Witte, 2012, p. 13). While the liability factor is more match to unemployed, homeless, or people with serious illness. Those situations can make people think that they are just troubles or even burdens to others (Joiner, Van Orden, Witte, Cukrowicz, \& Braithwaite, 2011, p. 13). One of the situations that make people recognize themselves as liability is because they cannot meet parents' demands (Joiner, 2008, p. 111). The second aspect is Low Belongingness. According to Joiner's paper named The Interpersonal Theory of Suicide, people need to obtain their "need to belong". If they fail to complete their "need to belong", they will fall into loneliness and this loneliness will lead them into passive suicidal ideation (Joiner, Van Orden, Witte, Cukrowicz, \& Braithwaite, 2011, p. 9-10). One significant factor that makes people have low belongingness or feel disconnected from their surrounding is because of lack of reciprocally-caring relationship (Joiner, Van Orden, Witte, Cukrowicz, \& Braithwaite, 2011, p. 10). Then, the last aspect is Acquired Ability to Enact Lethal Self-Injury. Both the first and the second aspects will not lead people to commit suicide because those aspects are only passive ideation unless they can do self-harm and desire to do further action. Joiner explained that people who commit suicide must lose their fear of death. The fear of death can be reduced by increasing physical pain tolerance or self-harm (Joiner, 2008, p. 20). One of the causes people does self-harm because of impulsivity. Impulsivity in people exists because many painful experiences occur over and over again (Bender, 2009). Joiner also added painful and 
provocative experiences as the further factors of people who commit suicide (Joiner, Van Orden, Witte, Cukrowicz, \& Braithwaite, 2011, p. 15-18). I use this theory to show that Richie has faced the three elements that lead him to take his own life.

\section{THE CAUSES OF RICHIE TENENBAUM'S SUICIDE ATTEMPT}

Richie Tenenbaum is a successful and talented tennis player when he was a kid. At the age of 17, he becomes a professional tennis player. In the movie, the young Richie is depicted as a happy kid. He is close to Royal his father and Margot his adopted sister yet his crush. However, his life is changing when he turns 26 years old. He fails in the match miserably. After that, he travels alone for years; secludes himself from his family and friends.

\subsection{Richie's Negative Self-Schema}

Richie's negative self-schema, which rooted in his childhood, is one of the root reasons that later will encourage his suicidal behavior in adult life. At the beginning of the movie, Richie is depicted as a happy kid. However, his happiness is fading because he faces many unpleasant or negative situations and experiences, which leads him to form a negative self-schema. Those unpleasant experiences are his parents' divorce and criticism from the father.

\subsubsection{The Parents' Divorce}

The first family conflict that forms Richie's negative self-schema is from his divorced parents. Richie is close to his father since young.

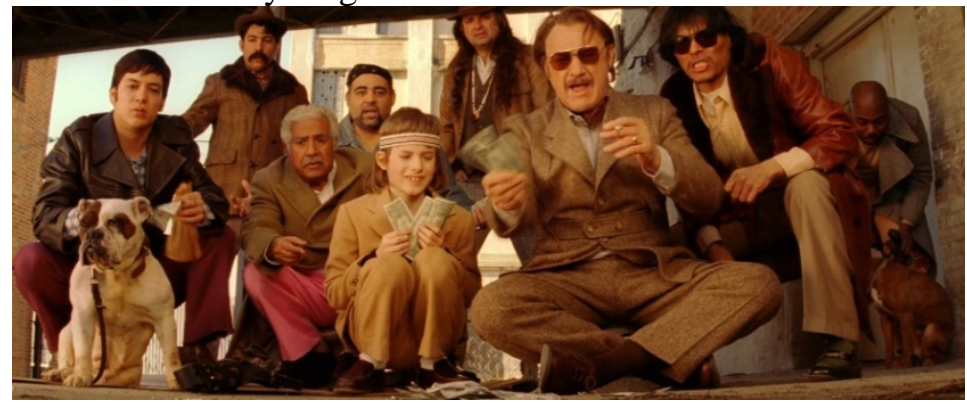

Picture 1: Richie (the kid) and his father

(fanning his money) in a dog fight

From the picture above, the young Richie looks happy when he is having fun together with his father, Royal. However, the situation is changing when Richie's father, Royal, decides to divorce his wife and leaves the children under her care. The children of Tenenbaums have to adapt to that situation. The young Richie has to face the fact that his parents want to divorce which is illustrated in the dialogue below and Picture 2
MARGOT : Are you getting divorced?
ROYAL : At the moment, no. But it doesn't look good.
RICHIE : Do you still love us?
ROYAL : Of course, I do.
CHAS : Do you still love Mom?
ROYAL : Very much. But she asked me to leave, and I had
to respect her position on the matter. 


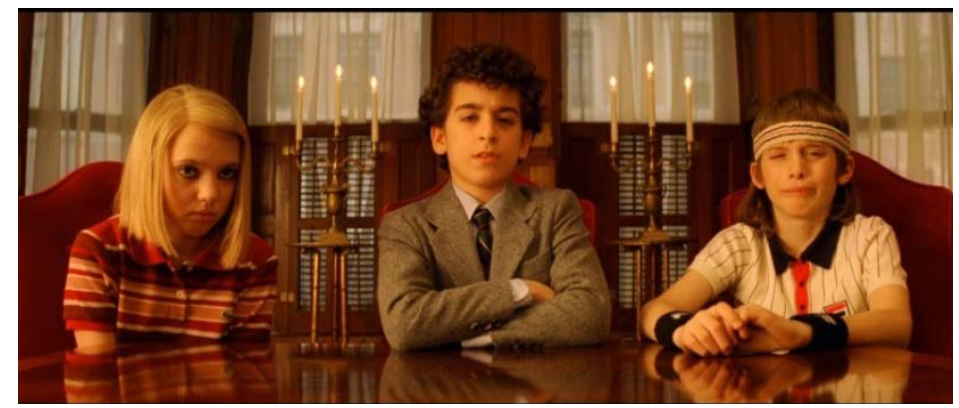

Picture 2: Richie's (on the right) expression when his father discusses about divorce

The moment when the children of Tenenbaums are told that their father has to leave the house because their parents are getting a divorce shows that the three children have different perceptions in dealing with the fact. Comparing to the expression from the other kids, Richie's expression shows that he is the saddest and the most brokenhearted. Richie's expression shows that he is about to cry. He has squinting eyes and compressed lips, meaning that he is trying to hold the tears. Crying is mostly identified as the result of sadness or distress (Pierre, 2018, para. 6). Crying is the reaction because there is painful emotion within them (para. 11). Richie's reaction when his father talks about the divorce shows that he takes the separation of his parents very hard, most likely because he has the closest relationship with his father. The father-child relationship plays a big role in creating children's self-concept during childhood. If the relationship is ruined it can affect children's behavior, performance, and self-esteem into negative outcomes (Kanoy, 1980). The same goes for Richie's experience. Because Richie and his father's relationship is ruined, it creates a negative self-schema within Richie. Later, Richie tends to become a person who has low self-esteem in his adulthood because after the divorce Richie loses his father, who plays a big role in creating Richie's self-concept.

\subsubsection{The Father's Criticism}

Richie's negative self-schema also comes from harsh criticism in his childhood experience. In addition, criticism is used by parents to discipline their children. However, giving too much criticism and less praise to children can affect children's cognition and behavior (Swenson, et al., 2015, p. 2). The same case happens in this movie. Instead of praising the children, the father mocks the children's performance which is illustrated in Picture 3.

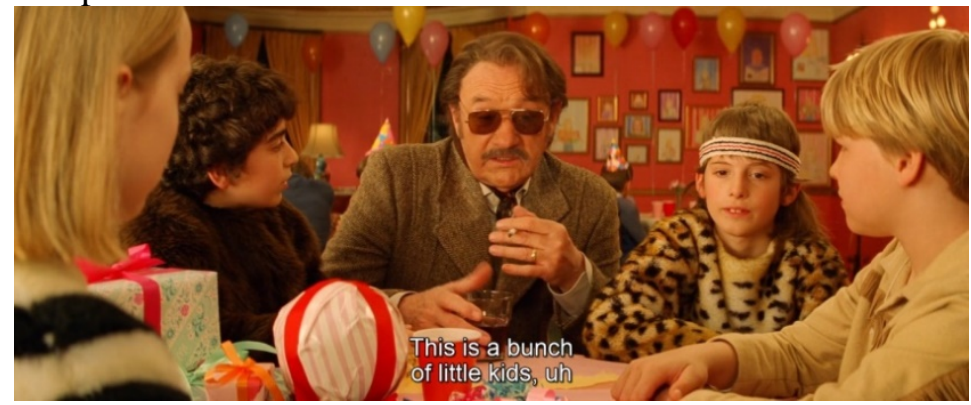

Picture 3: Richie (wearing leopard costume) is listening to his father's comment

From the picture above, the young Richie looks hurt because his father only mocks the performance when he and his siblings already give their best. Royal even states "the performance seems unbelievable" and "the performance is just a bunch of little kids wearing animal costumes" directly to the children during the conversation. During the conversation, Richie tends to look at the ground rather than look into his father's eyes. Comparing to the other kids in Picture 3, Richie is the only kid who looks away and intentionally avoids eye contact 
when Royal is talking. Umoh (2017) mentioned that someone who tends to avoid eye contact while having a conversation is a person who lacks confidence (para. 9). Richie, who takes his Father's criticism harder than his siblings, avoids eye contact because his confidence is depleted. In addition, Beck \& Alford (2009) mentioned one of the examples that can contribute to increasing someone's negative schema is criticism. Being harshly criticized by their father gives a big scar in Richie and his siblings' hearts. The proof is after that incident, Richie and his siblings agree that they will not invite their father to their parties anymore. Also, this harsh criticism influences Richie's mindset that he should meet his father's expectations in his adult life.

\subsection{Richie’s Perceived Burdensomeness}

In his adult life, Richie perceives himself as a burden to himself and his surroundings. According to the Interpersonal Theory of Suicide, liability can construct people's perception as a burden to others (Joiner, Van Orden, Witte, Cukrowicz, \& Braithwaite, 2011, p. 12). In addition, low self-esteem is a significant factor that creates perception of burdensomeness (Joiner T. E., Van Orden, Cukrowicz, \& Witte, 2012, p. 13). Through the movie, Richie shows that he is a person with low self-esteem and possesses the feeling of liability which later contributes him to become suicidal.

\subsubsection{Richie’s Low Self-Esteem}

Richie perceives himself as a burden is caused by his low self-esteem. Self-esteem is "belief and confidence in your own ability and value" (Cambridge Dictionary, n.d.). In this movie, Richie shows that he is a person with low self-esteem when he faces a big failure.

ANNOUNCER (V.O.): (about Richie's hesitation) That's seventy-two unforced errors for Richie Tenenbaum. He's playing the worst tennis of his life. What's he feeling right now, Tex Hayward?

TEX (V.O.) : I don’t know, Jim. There's obviously something wrong with him. He's taken off his shoes and one of his socks, and actually, I think he's crying.

(The camera angle shots at Richie's upset expression) ANNOUNCER (V.O.): Who's he looking at in the friends' box, Tex?

TEX (V.O.) : That's his sister, Margot, and her new husband, Raleigh St. Clair. They were just married yesterday, Jim.

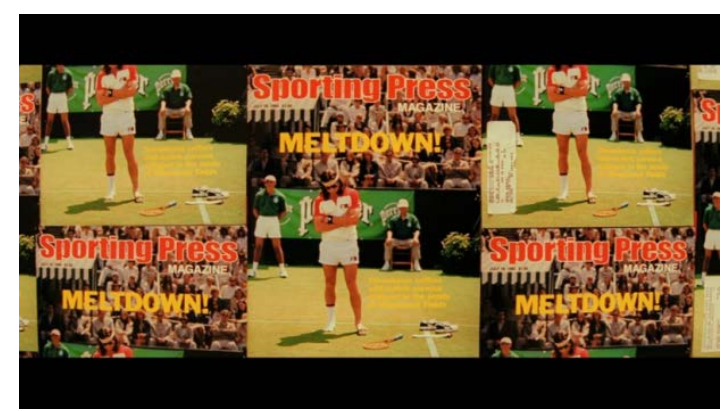

Picture 4: Richie's loss at competition is widely spread out through the news 
The dialogue above tells about how two sports announcers are commenting on Richie and Gandhi's match. The match is being broadcasted on live through television so everybody could see the match. Richie's failure is not only spread out through national TV but he also appears in the cover of a magazine which is illustrated in Picture 4. In the picture, Richie looks at the ground and crosses his arms. Richie wants to comfort himself because he has faced stressful moment that affects his performance. "When we're stressed, we receive comfort by crossing our arms across the torso so we can then reach across and massage our arms with our opposite hands" (Navarro, 2014, para. 4). People with low self-esteem tend to avoid eye contact when having a conversation with others (Noel, 2016, para. 9). Because of the failure, Richie shows he is in distress from the way he behaves. He crosses his arms and even avoids eye contact to everyone which shows that he has low self-esteem. Richie's low self-esteem can also be seen on his action after the failure. Beck's concept of cognitive distortion explained about overgeneralization which is "a state of drawing a general conclusion based on people's perspective about their ability, performance, or their effort on the basis of a single incident" (Beck \& Alford, 2009, p. 203-205). This concept is the result of someone who has a negative self-schema that can influence self-esteem within him. After facing negative life events during his childhood, Richie tends to have low self-esteem. From the dialogue above, the announcer says "he's playing the worst tennis of his life" to Richie's performance. Because Richie has low self-esteem, he then sees the announcer's statement as a fact. Then, it makes he think he is the worst tennis player. People with low self-esteem tend to avoid the source of the problem "by distancing themselves emotionally from it rather than taking the risks necessary to deal with the problem more directly" (Mruk, 2013, p. 162). Richie shows the behaviour of a person with low self-esteem when he decides to quit from being a tennis player. Richie's decision shows that he want to avoid what made him fail which is the tennis itself. Self-esteem has a significant part to create someone's perception of burdensomeness (Joiner T. E., Van Orden, Cukrowicz, \& Witte, 2012, p. 13). Baumeister and Leary (as cited in Joiner T. E., Van Orden, Cukrowicz, \& Witte, 2012) mentioned that self-esteem can create "interpersonal inclusion or exclusion. They classified "that individuals feel good about themselves when they perceive inclusion and feel bad about themselves when they perceive exclusion”. Richie who fails at a match, feels excluded because he has low self-esteem. The media that talks about his failure makes Richie feel apart from the thing he used to do. Because of that, Richie intentionally retires from tennis and secludes himself.

\subsubsection{Richie's Feeling of Liability}

In adult life, Richie falls into the feeling of becoming a liability. Liability is the view that the action that you do can become burdens to others (Joiner, Van Orden, Witte, Cukrowicz, \& Braithwaite, 2011, p. 12). In the movie, there is a scene that implicitly shows that Richie is liable for his father which is illustrated in the dialogue below.

\begin{tabular}{|c|c|}
\hline ROYAL & : It’s a shame, isn’t it? \\
\hline RICHIE & : What? \\
\hline ROYAL & $\begin{array}{l}\text { : You probably had another good two to three years of } \\
\text { competitive play in you. }\end{array}$ \\
\hline RICHIE & : (shrugs) Probably \\
\hline ROYAL & $\begin{array}{l}\text { : I had a lot riding on that match, you know. Financially } \\
\text { and personally. (cont'd) Why'd you choke out there that } \\
\text { day, Baumer? }\end{array}$ \\
\hline RICHIE & : (pause) I don’t know, Dad \\
\hline ROYAL & : I kind of disappeared after that, didn’t I? \\
\hline RICHIE & $\begin{array}{l}\text { : (shrugs) Yeah, but I understood. I know you're not very } \\
\text { good with disappointment. }\end{array}$ \\
\hline OYAL & : (nods) \\
\hline
\end{tabular}




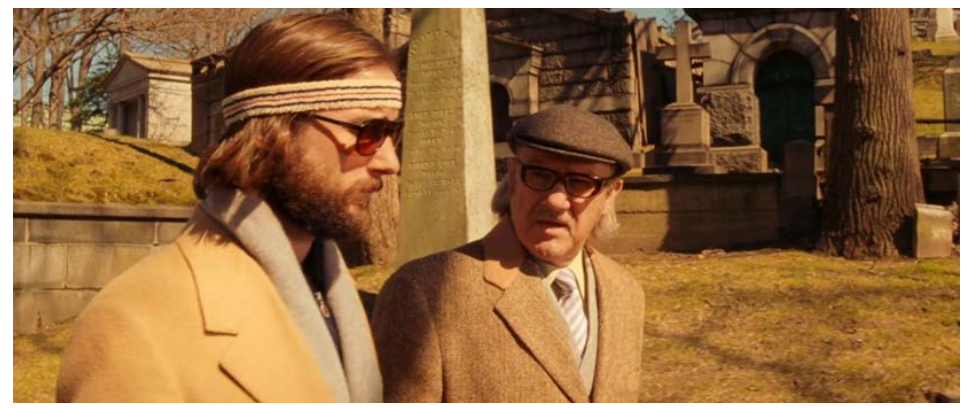

Picture 5: Richie's (on the left) expression when his father (on the right) mention about Richie's past failure

Picture 5 shows that Richie seems uncomfortable with the conversation with his father about his failure because in this scene he tends to look at the ground and avoid the eye-contact while talking to his father. He does not even try to give an explanation or defend himself against his father when his father says about Richie's failure. Joiner explained that people who see themselves as burdens are sometimes because they are unable to meet their parents' expectations (Joiner, 2008, p. 111). Richie's father says that he "had a lot riding on that match" means that he has a big expectation that his son will win the match. Unfortunately, Richie is unable to surpass his father's expectation at that time yet he makes his father leaves the match. By saying he understands that his father does not like to be disappointed, on the other hand, Richie claims that his failure is a disappointment and a burden for his father. Through this conversation, Richie has the feeling of liability because he cannot change the fact that his failure makes his father feels disappointed and a burden because he fails to meet his father's expectation.

\subsection{Richie’s Low Belongingness}

In his adult life, Richie also faces many unpleasant experiences that make him have low belongingness. Joiner mentioned several factors that make someone has low belongingness such as social disconnectedness, lack of reciprocal relationship, loneliness, etc (Joiner, Van Orden, Witte, Cukrowicz, \& Braithwaite, 2011, p. 9-10). Throughout the movie, Richie shows that he has low belongingness. It can be seen when Richie secludes himself from society, he faces a cold-relationship with his brother, and he suffers from betrayal by his family and his best friend.

\subsubsection{Richie’s Loneliness}

Richie's low belongingness can be seen when he isolates himself in loneliness. Loneliness is one of the factors that can decrease someone's belongingness (Joiner, Van Orden, Witte, Cukrowicz, \& Braithwaite, 2011, p. 10). There is a scene from the movie when Richie feels lonely when he is traveling alone after he retires from being a tennis player.

RICHIE : Read it back to me so far, Pietro.

SHIP CREW : Dear Eli, I'm in the middle of the ocean. I haven't left my room in four days. I've never been more lonely in my life, and I think I'm in love with Margot.

From that dialogue above, Richie confesses that he is very lonely. He uses the words "more lonely" means that he has faced loneliness before but this time is worse than before. According to Joiner, human needs relationship from others because everyone has a "sense of belonging" or "need to belong" (Joiner, Van Orden, Witte, Cukrowicz, \& Braithwaite, 2011). "Sense of belongingness can be found in family, friends, or even in social media" (Hall, 2014). Through the movie, Richie, who used to live with his mother and siblings, separates himself from his family and friends and he intentionally does that for years. It decreases his belongingness because he cannot fulfill his basic need (e.g. sense of belonging) since he travels alone far from 
his family and friends. Richie who isolates himself in loneliness also feels a lack of supports because during his vacation he is not accompanied by his family or friends. Thus, to gain social support Richie decides to contact his best friend, Eli.

\subsubsection{Richie’s Lack of Reciprocal Relationship and Social Connectedness}

In his adult life, Richie is lack of reciprocal relationship which makes him has low belongingness. Joiner (2011) mentioned that having a lack of reciprocal relationships can decrease someone's sense of belonging (p. 10). Through this movie, Richie fails to gain a reciprocal relationship with his brother.

Richie has faced a cold-relationship between him and his older brother, Chas until he is an adult. Because of that, Richie only befriends with his adopted sister and his childhood best friend. From the movie, Chas is more powerful than Richie. He is the oldest son, an independent, assertive, and ambitious child. He makes his own money at the age of 12 . Compared to Chas, Richie is not dominant. Richie is shyer and humbler than Chas. In their adult life, Chas even bullies Richie verbally which illustrates in the dialogue below.

$\begin{array}{ll}\text { ETHELINE } & \text { : Have you spoken to him about this? } \\ \text { RICHIE } & \text { : Briefly. And he agreed that - } \\ \text { CHAS } & \text { : I'm sorry. Maybe I'm a little confused. What are } \\ & \text { you suggesting? } \\ \text { RICHIE } & \text { : That he come here and stay in my room. } \\ \text { CHAS } & \text { : Are you out of your mind? } \\ \text { RICHIE } & \begin{array}{l}\text { (sincerely) No, I'm not. Anyway, I think he'd be } \\ \text { much more comfortable here than - }\end{array} \\ \text { CHAS } & \text { : Who gives a shit? } \\ \text { RICHIE } & \text { : I do. } \\ \text { CHAS } & \text { : You poor sucker. You poor, washed-up poppa's boy. }\end{array}$

There is another scene shows that Richie is not respected by Chas which is illustrated in the dialogue below.

CHAS : Looks like you and Dad are back together again, huh?

RICHIE : (pause) He's your dad, too, Chas.

CHAS : No, he's not. (pause) You really hate me, don't you?

RICHIE : (puzzled) No, I don't. I love you.

CHAS : Well, I don't know what you think you're going to get out of this. But believe me, whatever it is, it's not worth it!

RICHIE : I don't want to hurt you, Chas. I know what you and the boys have been through. You're my brother, and I love you.

CHAS : : Stop saying that! (left Richie alone)

From this dialogue, Chas seems that he wants to pick a fight to Richie from his sentences "are you out of your mind" and "who gives a shit". Chas also cuts Richie's explanation twice and it proves that he does not respect Richie. A reciprocal relationship can be found in a positive and caring relationship (Joiner, Van Orden, Witte, Cukrowicz, \& Braithwaite, 2011, p. 10). Through these dialogues, it is clearly shown that the relationship between Richie and Chas is not a caring or mutual relationship. Richie is being treated rudely by his brother while Richie is being sincere to his brother. Richie even says that he loves his brother two times to emphasize that he is sure about the feeling towards his brother. However, Chas does not care or even compromise 
towards Richie's sincere feeling yet he leaves Richie in the middle of the conversation. Because of this incident, Richie's belongingness is decreasing.

Another reason that makes Richie has low belongingness is because Richie lacks of social connectedness. Social connectedness means "an expression of the interdependent self in which the self and other are interconnected and mutually dependent on each other" (Lee, Draper, \& Lee, 2001). Richie fails to gain social-connectedness from the people he has trusted since childhood. Richie has trusted and put a belief towards his father since he is a kid. Richie who treasures his relationship with his father feels devastated because he losses a meaningful relationship. Lee, Draper \& Lee (2001) mentioned that social connectedness exists because there is interdependent action within both sides (p. 310). Richie undergoes a negative interdependent relationship because he is the only one who gives his trust to his father. Knowing that his father betrayed him, Richie feels disconnected from his relationship with his father.

Richie's lack of social connectedness also comes from Margot's and Eli's betrayal. Richie finds out that Margot has many love affairs with both man and woman, has a smoke habit since twelve years old, and even his relationship with Eli (Richie's best friend).

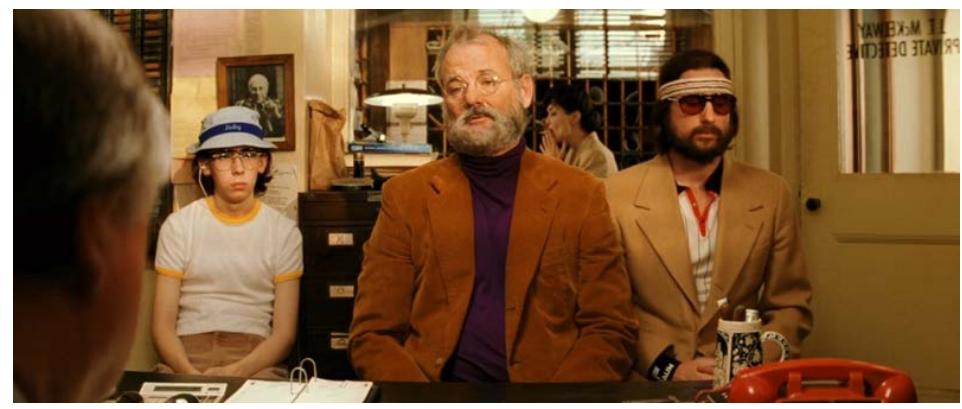

Picture 6: Richie’s (on the right) expression when he knows Margot's secrets

Picture 6 shows that Richie who is sitting on the right side looked puzzled after he knows about Margot's hidden secret. "When someone is disengaged, the amount of eye contact decreases, as we tend to look away from things that distress us" (Goman, 2019). Richie's body language shows that he separates himself from the conversation by looking at the other side of the room, avoiding eye contact towards the detective. The relationship that is ruined by betrayal cause a deeply painful emotion because "the person to whom we have disclosed and entrusted our deepest fears and vulnerabilities appears neither to care about our relationship nor to be committed to it" (Fitness, 2001, p. 3-4). Richie who has built trust towards Margot suffers from a deeply painful emotion because of the betrayal. In this case, Margot seems does not care about his relationship with Richie because she keeps silence about her secrets. In addition, Richie is not only betrayed by Margot but also by his childhood best friend, Eli. When Richie secludes himself, he even spares his time to contact Eli telling about his situation and his feeling towards Margot. This means that Richie trusts and feels dependent on his best friend. On the other hand, his best friend backstabs Richie. Eli does not tell the truth that he has a relationship with Margot. "Such experiences of betrayal trigger feelings of rejection, abandonment, and aloneness" (Fitness, 2001, p. 4). Those kinds of feelings refer to the feeling of disconnectedness where there is no interdependent relationship. In addition, it decreases Richie's belongingness because he is hurt by significant people whom he trusts and respects. 


\subsection{Richie’s Ability to Do Self-Harm and Desire to Die}

Richie who sees himself as a burden and has low belongingness also can do self-harm and a strong desire to take his own life. This capability occurs because of impulsivity. Joiner mentioned that impulsive behavior occurs because many negative experiences trigger someone does a reckless thing or even do self-harm (Bender, 2009). Richie's capability to self-harm begins when he does impulsive action the moment when Richie smashes the window glass.
RALEIGH : I believe she's having an affair. (pause) I'm
utterly devastated. I don't know where else to turn.
Will you advise me?
RICHIE : I don't know. What do you want to do?
RALEIGH : Well, I thought, perhaps -
RICHIE : Find the guy and get him?
RALEIGH : (pause) Well, no. I thought we might -
RICHIE : (punches the window) Who do you think it might be?
RALEIGH : (hesitates) I don’t know, at the moment.

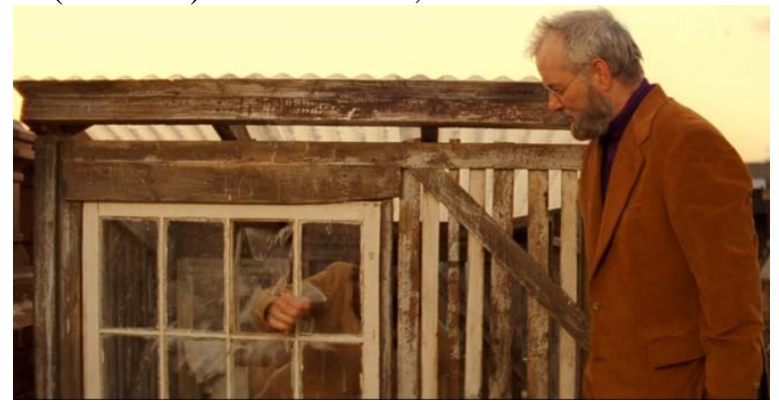

Picture 7: Richie (on the left side) punches the window glass

The dialogue above shows that Richie seems like having an anger feeling because his crush is having an affair. When people angry and cannot control emotion usually they do a reckless thing like destructive action. From the dialogue, Richie and Raleigh are having a conversation about Margot which makes Richie punches the window. This impulsivity often happens because someone faces a painful experience (Joiner, 2009, p. 3). From the conversation, Richie is both angry and curious about Margot's affair. Picture 7 tells about Richie's action is concluded to impulsivity because he breaks the window without proper thought and with no fear.

In the end, Richie has a strong intention to die. The moment before he attempts, he is talking to himself in the mirror, telling that he will kill himself which is illustrated in Picture 8.

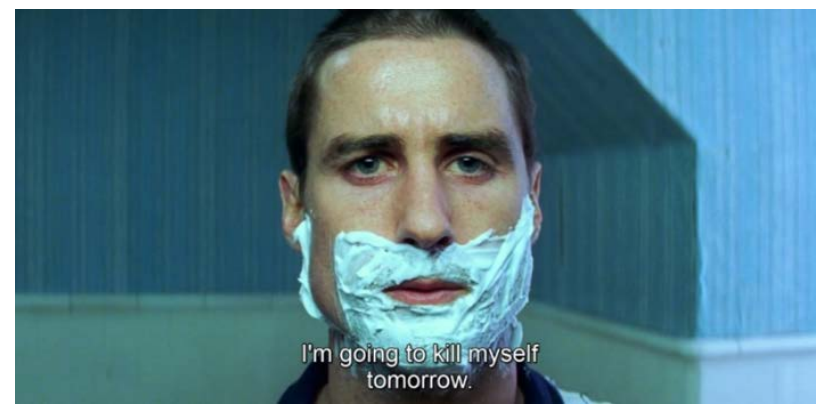

Picture 8: Richie’s intention to die

Picture 8 shows that Richie has a strong desire to die. This is a powerful sentence from him because he is finally showing his feeling directly. "The most dangerous form of suicidal desire is caused by the simultaneous presence of two interpersonal constructs-thwarted (low) belongingness and perceived burdensomeness" (Joiner, Van Orden, Witte, Cukrowicz, \& 
Braithwaite, 2011, p. 1). Until he is an adult, Richie often faces many painful experiences that make him become a person who perceives himself as a burden and who has low belongingness. Eventually, he has an impulsive behavior because he cannot handle his emotion. Richie says that he will commit suicide tomorrow but he tries to take his own life on that day, right after he confesses his intention.

\section{CONCLUSION}

Through this analysis, I find that self-esteem and social support are the important roles in deciding someone's suicide decision. Self-esteem is constructed during childhood. When the childhood life is filled with negative or painful experiences, it can influence someone's mindset in the future. In the movie, Richie's lack of self-esteem causes him trapped into wrong perception. Social support plays a big role as well in constructing someone's feeling of "need to belong”. It is like support system when someone perceives exclusion from something or other people, he or she will not become hopeless because they know that they belong to a part of connection. In the movie, Richie loses the connection from everyone he holds onto. Because of that, he feel like he does not belong to this world and he decides to attempt suicide.

In conclusion, someone may attempt to commit suicide because he or she has gone through many painful experiences which begin from childhood. Someone attempts suicide is because of painful experiences like criticism and divorced parents from the childhood which construct the negative self-schema. The other reasons of someone's attempt to suicide are negative interpretation in seeing himself or herself as a burden, low belongingness which makes him or her feels socially disconnected from the surroundings, and the ability to do self-harm.

\section{REFERENCES}

Beck, A. T., \& Alford, B. A. (2009). Depression: Causes and treatments.

Bender, T. W. (2009). Suicidality and impulsivity: A test of the mediatingrRole of painful experiences.

Fitness, J. (2001). Betrayal, rejection, revenge, and forgiveness: An interpersonal script approach.

Goman, C. K. (2019, January). The body language of disengagement-from head to toes. Retrieved from American Management Association: https://www.amanet.org/articles/the-body-language-of-disengagement-from-head-totoes/

Grych, J. H., \& Fincham, F. D. (1990). Marital conflict and children's adjustment: A cognitivecontextual framework.

Hall, K. (2014). Create a sense of belonging. Retrieved from Psychology Today: https://www.psychologytoday.com/us/blog/pieces-mind/201403/create-sense-belonging

Joiner, T. (2008). Joiner, T. (2009). Revisiting impulsivity in suicide: Implications for civil liability of third parties. Why people die by suicide. London.

Joiner, T. E., Van Orden, K. A., Cukrowicz, K. C., \& Witte, T. K. (2012). Thwarted belongingness and perceived burdensomeness: Construct validity and psychometric properties of the Interpersonal Needs Questionnaire.

Joiner, T., Van Orden, K., Witte, T., Cukrowicz, K., \& Braithwaite, S. (2011). The interpersonal theory of suicide.

Kanoy, K. W. (1980). Parent-child relationships and self concept: A comparison of children from divorced and intact amilies.

Kestinga, M.-L., \& Lincoln, T. M. (2013). The relevance of self-esteem and self-schemas to persecutory delusions: A Systematic Review.

Lee, R. M., Draper, M., \& Lee, S. (2001). Social connectedness, dysfunctional interpersonal behaviors, and psychological distress: Testing a mediator model. 
Mittell, J. (2004). Genre and television: From cop shows to cartoons in American culture.

Mruk, C. J. (2013). Defining self-esteem as a relationship between competence and worthiness: How a two-factor approach integrates the cognitive and affective dimensions of selfesteem.

Navarro, J. (2014, October). 9 truths exposing a myth about body language. Retrieved from Psychology Today: https://www.psychologytoday.com/us/blog/spycatcher/201410/9truths-exposing-myth-about-body-language

Noel, K. (2016, April). A body-language expert reveals the no. 1 indicator of confidence and how you can cultivate it. Retrieved from Business Insider Singapore: https://www.businessinsider.sg/body-language-indicator-of-confidence-2016$4 /$ ? $r=U S \& I R=T$

Pierre, J. (2018, April 23). Why do we cry? Exploring the psychology of emotional tears. Retrieved from Psychology Today: https://www.psychologytoday.com/us/blog/psychunseen/201804/why-do-we-cry-exploring-the-psychology-emotional-tears

Swenson, S., Ho, G. W., Budhathoki, C., Belcher, H. M., Tucker, S., Miller, K., et al. (n.d.). Parents' use of praise and criticism in a sample of young.

Thorpe, V. (2019, May). Seriously funny: Why we fell in love with dramedies. Retrieved from The Guardian: https://www.theguardian.com/tv-and-radio/2019/may/11/why-we-fell-inlove-with-dramedies

Umoh, R. (2017, August 17). How making eye contact can help you appear more confident at work. Retrieved from CNBC Make It: https://www.cnbc.com/2017/08/17/how-makingeye-contact-can-help-you-appear-more-confident-at-work.html

Wheel, E. (2015). The rising popularity of the dramedy. Retrieved from The Emory Wheel: https:/emorywheel.com/the-rising-popularity-of-the-dramedy/ 